Originalien

Z Rheumatol 2021 · 80:432-446 https://doi.org/10.1007/s00393-020-00944-7 Accepted: 27 November 2020

Published online: 21 December 2020

(c) The Author(s) 2020

\section{Redaktion}

U. Müller-Ladner, Bad Nauheim

U. Lange, Bad Nauheim

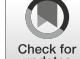

L.-J. Chen ${ }^{1}$ - Y.-J. Zhou ${ }^{2}$ - Z.-H. Wen ${ }^{1}$ F. Tian' · J.-Y. Li ${ }^{1}$

'Department of Rheumatology and Immunology, The Affiliated ZhuZhou Hospital of XiangYa Medical College, Central South University, ZhuZhou, China

${ }^{2}$ Department of Neurosurgery, Union Hospital, Tongji Medical College, Huazhong University of Science and Technology, Wuhan, China

\title{
Efficacy and safety of iguratimod combined with methotrexate vs. methotrexate alone in rheumatoid arthritis
}

\section{A systematic review and meta-analysis of randomized controlled trials}

\section{Introduction}

Rheumatoid arthritis (RA) is an inflammatory disease of synovial joints that affects approximately $1 \%$ of the population [1]. In the absence of treatment, deteriorating joints can result in pain and stiffness, which limit physical function and lead to long-term disability [2]. RA is a potentially destructive disease that has a profound impact on functioning and quality of life among patients. At present, RA treatment remains a challenge for rheumatologists worldwide. Based on the course, disease activity, prognostic factors, and prior experience with disease-modifying antirheumatic drug (DMARDs) in the treatment of RA, the American College of Rheumatology (ACR) 2015 guidelines recommend the use of traditional antirheumatic agents and biological DMARDs. If methotrexate (MTX) is not found to be effective, methotrexate in combination with other DMARDs such as biologics will be recommended. However, the use of biological DMARDs to treat RA is not suitable for all patients for various reasons, including complications, side effects, uncertain efficacy, and high costs that prevent their use. Therefore, a new anti-rheumatic drug combined with MTX is urgently needed in the treatment of RA, especially for drug switching and cost reduction. Iguratimod (IGU) is a new synthetic diseasemodifying antirheumatic drug (small molecule), whereby its mechanism of action is still not completely clear [3]. At the molecular level, iguratimod inhibits the invasiveness of rheumatoid synovial fibroblasts by decreasing matrix metalloproteinase (MMP-1 and MMP3) production [4], and it also inhibits the activation of MAPKs and the NFkappa B pathway in RANKL-induced osteoclastogenesis in RAW264.7 cells, which can prevent bone destruction [5]. The production of $\operatorname{IgG}, \operatorname{IgM}$, and $\operatorname{IgA}$ was significantly reduced in active RA patients who were treated with IGU compared with those treated with placebo in some studies [6,7]. Therefore, IGU has been considered a clinically useful DMARD with a unique mechanism of action, and its improvement rate of the ACR20 was not lower than that of sulfasalazine in patients with active RA (57.7\% compared with $63.1 \%$ ) [8]. Although the available study population is mainly East Asian (Japan and China up to date), and with the consequence that transfer of results to other ethnicities is questionable, we still need this research to show the effect of IGU on RA for rheumatologists around the world. The current systematic review and metaanalysis aims to evaluate the efficacy and safety of IGU combined with MTX versus MTX alone for RA.

\section{Methods}

Our study was conducted following a protocol registered in PROSPERO (CRD42020157711). The methods used in the review conformed to the established Preferred Reporting Items for Systematic Reviews and Meta-Analyses (PRISMA) guidelines [9].

\section{Inclusion criteria}

The inclusion criteria included the following: 1) studies conducted in a human population aged $>18$ years; 2 ) studies in which all patients were diagnosed with RA based on the ACR or the European League Against Rheumatism (EULAR) classification criteria; 3) studies that evaluated the combination of IGU and MTX therapy in RA; 4) studies with outcome data including ACR20, ACR50, ACR70, and adverse events; 5) randomized placebo-controlled clinical trials or trials in which the treatment arm was compared with a control arm; and 6) studies that were available in all languages. The full text of potentially related 
Table 1 PICOS criteria for inclusion and exclusion of studies

\begin{tabular}{|c|c|c|}
\hline $\begin{array}{l}\text { Para- } \\
\text { meter }\end{array}$ & Inclusion criteria & Exclusion criteria \\
\hline $\begin{array}{l}\text { Partici- } \\
\text { pant }\end{array}$ & $\begin{array}{l}\text { Studies conducted in a human population } \\
\text { aged }>18 \text { years } \\
\text { Studies in which all patients were } \\
\text { diagnosed with RA based on ACR or } \\
\text { EULAR classification criteria }\end{array}$ & $\begin{array}{l}\text { Nonhuman studies (animal studies) and } \\
\text { studies among children } \\
\text { Studies in which patients diagnosed with } \\
\text { RA were treated with a combination of } \\
\text { other drugs (DMARDs) }\end{array}$ \\
\hline $\begin{array}{l}\text { Inter- } \\
\text { vention }\end{array}$ & $\begin{array}{l}\text { Studies regarding the combination of } \\
\text { iguratimod and methotrexate }\end{array}$ & Studies with a duration $<3$ months \\
\hline $\begin{array}{l}\text { Compar- } \\
\text { ison }\end{array}$ & $\begin{array}{l}\text { Studies that included comparisons } \\
\text { between treatment with placebo + MTX or } \\
\text { MTX (alone) }\end{array}$ & $\begin{array}{l}\text { Studies without a clear control arm or } \\
\text { placebo arm }\end{array}$ \\
\hline $\begin{array}{l}\text { Out- } \\
\text { come }\end{array}$ & $\begin{array}{l}\text { Studies in which ACR20, ACR50, and } \\
\text { ACR70 were used as the evaluation criteria } \\
\text { and as efficacy indicators } \\
\text { Studies with safety evaluation }\end{array}$ & $\begin{array}{l}\text { Studies without end-of-trial outcome data } \\
\text { (ACR20, ACR50, ACR70, and adverse } \\
\text { events) }\end{array}$ \\
\hline $\begin{array}{l}\text { Study } \\
\text { design }\end{array}$ & $\begin{array}{l}\text { Randomized controlled trials with parallel } \\
\text { designs } \\
\text { Studies available in all languages }\end{array}$ & $\begin{array}{l}\text { Observational studies (which were } \\
\text { excluded from the meta-analysis but were } \\
\text { reviewed), studies without a placebo or } \\
\text { control arm, and editorials and opinion } \\
\text { pieces }\end{array}$ \\
\hline
\end{tabular}

studies was extracted, and the methods and results of the trial were reviewed. When necessary data could not be determined, every effort was made to contact the study authors.

\section{Exclusion criteria}

The exclusion criteria included the following: 1) nonhuman studies (animal studies) and studies in children; 2) studies in which patients diagnosed with RA were treated with a combination of other DMARDs; 3) studies with a duration $<3$ months; 4) non-RCT studies and studies without a clear control arm or placebo arm; and 5) studies without end-of-trial outcomes (ACR20, ACR50, ACR70, and adverse events). The participant, intervention, comparison, outcome, and study design (PICOS) data are presented in - Table 1.

\section{Literature search strategy}

Two independent investigators searched for original RCT studies related to the combination of IGU and MTX therapy in RA published before November 1, 2019, in PubMed, Cochrane Library, Embase, the China National Knowledge Infrastructure (CNKI), the Chinese
Biomedical Literature Database (CBM), and WanFang Data using the medical subject header (MeSH) terms "Iguratimod" or "T-614" and "Methotrexate" or "Amethopterin" or "MTX" and "Rheumatoid Arthritis" or "Arthritis, Rheumatoid" or "RA." Additionally, we searched clinical trial registry websites (http://www.ClinicalTrials.gov and http://www.chictr.org.cn) to identify trials that had been completed but not yet published, as well as all ongoing trials with available results and data. When multiple publications were found regarding the same trial, we used the latest or the most complete report of the trial. If it included complete information about the study design, participant characteristics, interventions, and outcomes, we also considered conference summaries. Additional RCTs were identified from the reference lists of relevant full-text articles retrieved.

\section{Data extraction}

Data were extracted independently by two investigators (LJ-C and YJ-Z). A third investigator (JY-L) resolved the differences between the two investigators to reach a consensus. Only the results of outcomes that had been prespecified in the protocol were extracted from the studies. The following study characteristics were extracted: study title, unique study name or ID, primary author, contact information, publication type, funding and conflicts of interest, year the study was initiated and completed, country of origin of the study, study setting, study design (e.g., multicenter or single center), and study inclusion and exclusion criteria. The following study patient characteristics were extracted: total number of participants screened for the study, number of participants randomized into each study arm, and participant age, sex, and race/ ethnicity. The following intervention and comparison group characteristics were collected: all information provided by the study for the regimen (therapeutic agent name, dose, route, frequency, and total duration of administration). The study outcomes were summarized. The adverse event definitions and the total number and individual number of events experienced were also extracted. Screening of the data extraction forms was completed to identify the missing or extraneous fields and to facilitate the most effective extraction process (LJ-C and $\mathrm{YJ}-\mathrm{Z}$ ).

\section{Assessment of risk of bias}

We assessed the methodological quality of the included trials using the Cochrane Collaboration tool. Studies were graded as having a "low risk", "high risk," or "unclear risk" of bias across the seven specified domains [10]. We also used the seven-point Jadad scale, which includes randomization, double-blinding, and sequential removal of one study at a time, a practice that is in agreement with the methods of other meta-analyses performed in this context [11]. Assessments were stored and managed in RevMan 5.3 (The Nordic Cochrane Centre, The Cochrane Collaboration, Copenhagen, Danmark; 2014).

\section{Data synthesis}

For continuous data, the mean difference (MD) was determined using the DerSimonian and Laird method if the 
Z Rheumatol 2021 · 80:432-446 https://doi.org/10.1007/s00393-020-00944-7

(c) The Author(s) 2020

\section{L.-J. Chen · Y.-J. Zhou ·Z.-H. Wen · F. Tian · J.-Y. Li}

\section{Efficacy and safety of iguratimod combined with methotrexate vs. methotrexate alone in rheumatoid} arthritis. A systematic review and meta-analysis of randomized controlled trials

\section{Abstract}

The current systematic review and metaanalysis aims to evaluate the efficacy and safety of iguratimod (IGU) combined with methotrexate (MTX) versus MTX alone in rheumatoid arthritis (RA). Two independent investigators searched for original randomized controlled trials (RCTs) related to the combination of IGU and MTX in RA published before November 1, 2019, in PubMed, Cochrane Library, Embase, the China National Knowledge Infrastructure (CNKI), the Chinese Biomedical Literature Database (CBM), and WanFang Data. Additionally, we searched clinical trial registry websites. We assessed the methodological quality of the included trials using the Cochrane Collaboration tool and the seven-point Jadad scale. Statistical analyses were performed using Review Manager (RevMan) 5.3 (Copenhagen: The Nordic Cochrane Centre, The Cochrane Collaboration, 2014). Meta-regression and publication bias analyses were performed using Stata version 14 software (StataCorp., College Station, TX, USA). A total of 7 RCTs consisting of 665 participants, with 368 participants in the active arm and 297 in the placebo arm, were included in the meta-analysis. The American College of Rheumatology (ACR) value was better in the IGU + MTX group than in the MTX alone group, with a pooled relative risk (RR) for ACR20 (American College of Rheumatology $20 \%$ improvement criteria),
ACR50, and ACR70 of 1.40 (95\% Cl, 1.13-1.74), $2.09(95 \% \mathrm{Cl}, 1.67-2.61)$, and $2.24(95 \% \mathrm{Cl}$, $1.53-3.28)$, respectively. The results of the meta-analysis demonstrated that there was no statistical significance in adverse events (1.06 $(95 \% \mathrm{Cl}, 0.92-1.23))$. The combined treatment is an effective, safe, and economical treatment option for patients who do not respond well to methotrexate alone or for patients who cannot afford expensive biologics that have no confirmed efficacy.

Keywords

Iguratimod $\cdot$ Methotrexate $\cdot$ Rheumatoid arthritis · Meta-analysis · Randomized controlled trials

\section{Wirksamkeit und Sicherheit von Iguratimod in Kombination mit Methotrexat vs. Methotrexat allein bei rheumatoider Arthritis. Systematische Übersicht und Metaanalyse randomisierter kontrollierter Studien}

\section{Zusammenfassung}

Ziel der vorliegenden systematischen Übersichtsarbeit und Metaanalyse war es, die Wirksamkeit und Sicherheit von Iguratimod (IGU) in Kombination mit Methotrexat (MTX) versus MTX allein bei rheumatoider Arthritis (RA) zu untersuchen. Dazu suchten 2 unabhängige Untersucher in den Datenbanken PubMed, Cochrane Library, Embase, China National Knowledge Infrastructure (CNKI), Chinese Biomedical Literature Database (CBM) und WanFang Data nach Originalpublikationen randomisierter kontrollierter Studien (RCT) hinsichtlich der Kombination von IGU und MTX bei RA, die vor dem 1. November 2019 publiziert worden waren. Zusätzlich wurden Websites zu klinischen Studienregistern durchsucht. Die methodische Qualität der einbezogenen
Studien wurde anhand des Bewertungsschemas der Cochrane Collaboration und der 7 Punkte umfassenden Jadad-Skala beurteilt. Statistische Analysen wurden unter Einsatz des Programms Review Manager (RevMan) 5.3 (The Nordic Cochrane Centre, Kopenhagen, The Cochrane Collaboration, 2014) durchgeführt. Metaregressions- und Publikationsbiasanalysen wurden unter Verwendung der Software Stata, Version 14 (Fa. StataCorp., College Station, TX, USA) durchgeführt. In die Metaanalyse einbezogen wurden 7 RCT mit 665 Teilnehmern, davon $368 \mathrm{im}$ aktiven Studienarm und $297 \mathrm{im}$ Placeboarm. Der Score gemäß American College of Rheumatology (ACR) war in der Gruppe IGU + MTX besser als in der Gruppe mit MTX allein, das gepoolte relative Risiko
(RR) lag für ACR20, ACR50 bzw. ACR70 bei 1,40 (95\%-Konfidenzintervall, $95 \%$-Kl: 1,13-1,74); 2,09 (95\%-KI: 1,67-2,61) bzw. 2,24 (95\%-KI: 1,53-3,28). Die Ergebnisse der Metaanalyse zeigten, dass keine statistische Signifikanz in Bezug auf Nebenwirkungen vorlag (1,06 (95\%-KI: 0,92-1,23)). Die Kombinationstherapie ist eine wirksame, sichere und wirtschaftliche Behandlungsoption für Patienten, die nicht gut auf Methotrexat allein ansprechen oder für Patienten, die sich teure Biologika nicht leisten können, deren Wirksamkeit sich nicht bestätigt hat.

Schlüsselwörter Iguratimod $\cdot$ Methotrexat $\cdot$ Rheumatoide Arthritis - Metaanalyse $\cdot$ Randomisierte kontrollierte Studie same scale was used across studies [12]. Results for dichotomous data were provided as relative risks and analyzed using the Mantel-Haenszel method. We examined heterogeneity in results across studies using Cochrane's Q statistic, and inconsistency was quantified with the $\mathrm{I}^{2}$ statistic $(100 \% \times(\mathrm{Q}-\mathrm{df}) / \mathrm{Q})$, which represents the percentage of total variation across studies that is attributable to heterogeneity rather than chance [13].
We considered a $p$-value of less than 0.10 as indicative of substantial heterogeneity. When substantial heterogeneity was not observed, the pooled estimate calculated with the fixed-effects model was reported using the inverse variance method. When substantial heterogeneity was observed, the pooled estimate calculated with the random-effects model was reported using the DerSimonian and Laird method [12], which considers both within-study and between-study variation. Publication bias was evaluated via funnel plots (i.e., plots of study results against precision) and quantified with Begg's and Egger's tests $[14,15]$. However, if there were fewer than 10 studies included in the systematic review, funnel plot analysis was not performed. A twotailed $p$-value of less than 0.05 was considered statistically significant. Statistical analyses were performed using Review 


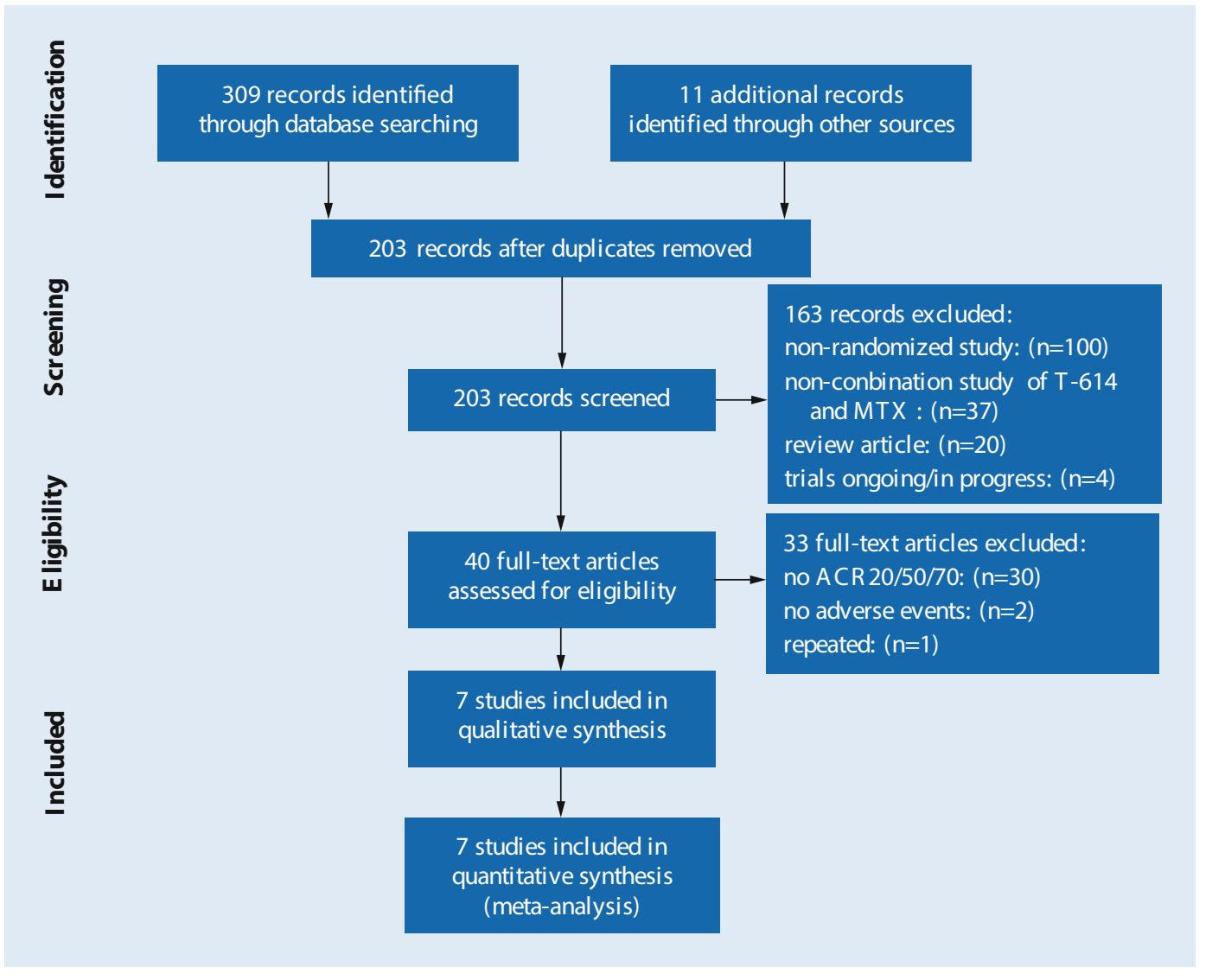

Fig. $1<$ A flowchart of the literature search and selection process. MTX methotrexate, ACR American College of Rheumatology

Manager (RevMan) 5.3. Meta-regression and publication bias analyses were performed using Stata version 14 software (StataCorp., College Station, TX, USA).

\section{Results}

\section{Search results}

All titles and abstracts found in the systematic review were independently screened by two researchers (LJ-C, YJZ). A third investigator (JY-L) resolved the differences among two investigators to reach a consensus. Our search strategy yielded a total of 320 publications potentially related to the combination of IGU and MTX therapy for RA. After removing duplicates, a total of 203 studies were identified. Following screening of the titles and abstracts, 163 manuscripts did not fulfill our inclusion criteria and were excluded, leaving 40 selected manuscripts. After subsequent screening, an additional 33 were excluded: 30 randomized controlled trials (RCTs) did not include the ACR20/50/70, 2 RCTs did not report adverse events, and 1 RCT was repeated in more than one bibliographic source. After the selection process, a total of 7 RCTs consisting of 665 participants with 368 participants in the active arm and 297 in the placebo arm were included in the meta-analysis [1, 16-21]. A Preferred Reporting Items for Systematic Reviews and Meta-Analyses flow diagram is included in • Fig. 1 to illustrate the number of publications included and excluded during each phase of screening.

\section{Study quality and risk assessment}

The included studies were published between 2013 and 2019. All included trials were randomized, with six phase II trials and three phase I trials. All seven trials were published as full manuscripts. Using the Cochrane Collaboration tool for risk of bias classification, we found the quality of the included studies to be generally good and fair (• Figs. 2 and 3). Trials were also ranked for Jadad score (- Table 2). The Jadad score of the in- cluded studies ranged from 3 to 4 . The overall quality of the included studies was high.

\section{Baseline characteristics of the included studies}

- Table 2 summarizes the baseline characteristics of the included studies. All the studies were RCTs; five studies did not report the blinding methods, one reported a double-blind, placebo-controlled design [16], and one study applied blinding methods to the investigators [1]. Six trials were from China and were single-center studies, and the remaining trial was from Japan and was a multicenter study [16]. All studies were conducted between 2013 and 2018, often for more than a year. Patients participating in these trials followed eligibility criteria determined by each unique trial, which usually included active RA patients older than 18 years and were based on ACR or EULAR criteria. Three trials [16-18] reported that the primary efficacy endpoint was the rate at which patients (the full analysis set) 


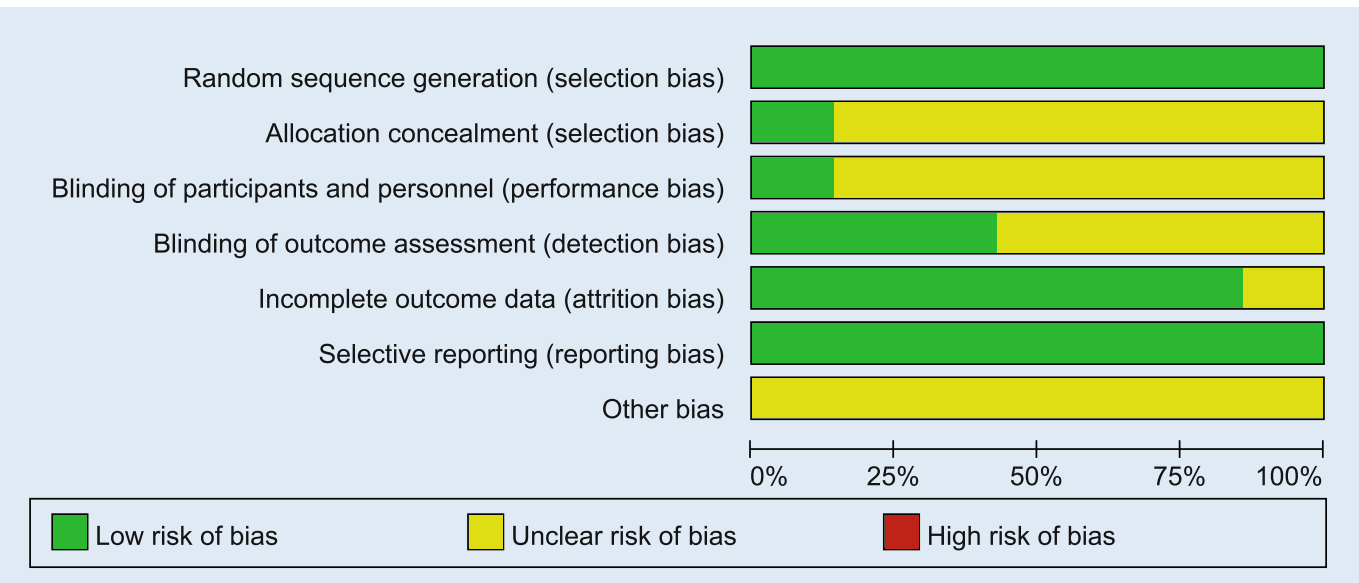

Fig. $2 \varangle$ Risk of bias in the seven included studies

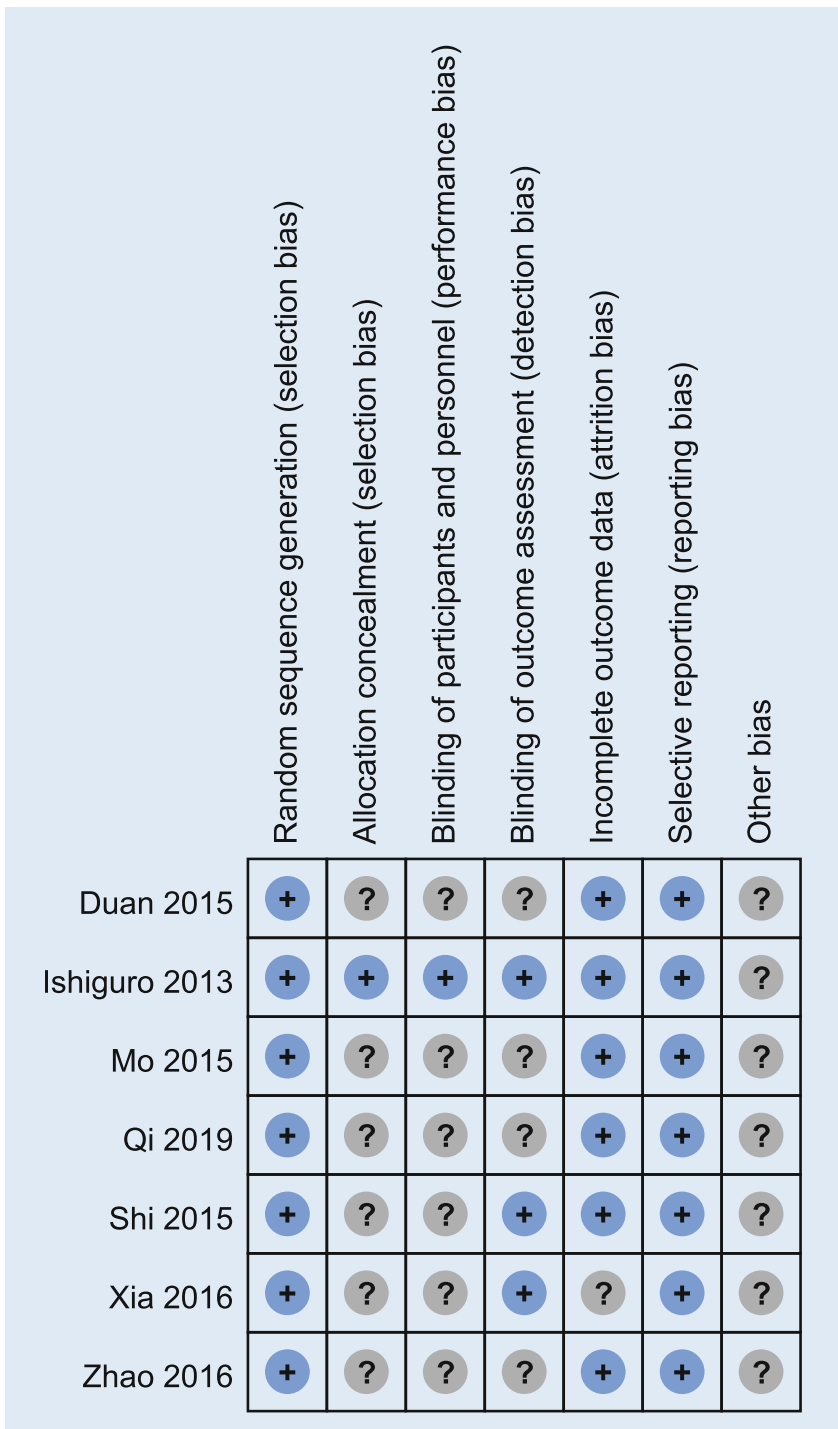

Fig. $3<$ Summary of the risk bias in the seven included studies. plus sign low risk of bias, question mark unclear risk of bias achieved ACR20 at week 24 or last observation carried forward (LOCF), and the rate of ACR20/50/70 was reported in the other four studies. Other outcomes are detailed in $\bullet$ Table 2 .

\section{Characteristics of participants, interventions, and comparator details in the included studies}

The characteristics of the participants, interventions, and comparator details in the included studies are presented in - Table 3. One study [1] did not report age and sex characteristics for each group (only total age averages and sex ratios were reported), and complete age and sex characteristics were obtained for one study [21] by contacting the authors. The average age of the participants was similar across all studies. The iguratimod dose used in the study [16] was $25 \mathrm{mg}$ once daily (QD) (0-4 weeks) and $25 \mathrm{mg}$ twice daily (BID) (5-24 weeks), and the remaining six studies were $25 \mathrm{mg}$ BID. The use of the MTX dose in three studies was phased using $10 \mathrm{mg} /$ week (0-4 weeks) and $12.5 \mathrm{mg} /$ week (5-24 weeks) $[17,20]$, and $7.5-10 \mathrm{mg} /$ week (0-4 weeks) and $10 \mathrm{mg} /$ week (5-24 weeks) [18]. However, there was no phased administration in four studies, including 6 or $8 \mathrm{mg} /$ week [16], $10 \mathrm{mg} /$ week $[1,21]$, and $15 \mathrm{mg} /$ week [19]. It is worth noting that four studies added complementary drugs. Two studies $[1,20]$ allowed the use of one NSAID ( $0.2 \mathrm{~g}$ celecoxib capsule, two times a day, oral) and (or) a small dose of a glucocorticoid (prednisone $7.5 \mathrm{mg} / \mathrm{d}$ or $10 \mathrm{mg} / \mathrm{d}$ ), and two studies allowed the 


\begin{tabular}{|c|c|c|c|c|c|c|c|}
\hline $\begin{array}{l}\text { Author, } \\
\text { year }\end{array}$ & Design & Country & $\begin{array}{l}\text { Study } \\
\text { period }\end{array}$ & Eligible population & $\begin{array}{l}\text { Primary } \\
\text { outcome }\end{array}$ & Other outcome(s) & $\begin{array}{l}\text { Jadad } \\
\text { score }\end{array}$ \\
\hline $\begin{array}{l}\text { Duan et al. } \\
2015 \text { [17] }\end{array}$ & $\begin{array}{l}\text { RCT, NR } \\
\text { (blinding), single } \\
\text { center }\end{array}$ & China & $\begin{array}{l}\text { January } \\
2013 \text { to } \\
\text { December } \\
2013\end{array}$ & $\begin{array}{l}2010 \text { ACR and EULAR, not treated with } \\
\text { any anti-rheumatism medicine or } \\
\text { biological agents prior to enrollment } \\
\text { and treatment }\end{array}$ & $\begin{array}{l}\text { ACR20, TJC, } \\
\text { SJC }\end{array}$ & $\begin{array}{l}\text { ACR50, ACR70, HAQ, } \\
\text { DAS28, ESR, CRP, APRs, } \\
\text { SDAI, VAS (PAP, PGA, PhGA) }\end{array}$ & 3 \\
\hline $\begin{array}{l}\text { Ishiguro } \\
\text { et al. } 2013 \\
\text { [16] }\end{array}$ & $\begin{array}{l}\text { RCT } \\
\text { double-blind, } \\
\text { placebo-con- } \\
\text { trolled, } \\
\text { multicenter }\end{array}$ & Japan & $\begin{array}{l}\text { August } \\
2009 \text { to } \\
\text { February } \\
2011\end{array}$ & $\begin{array}{l}\text { Active RA patients ( }<10 \text { years) based on } \\
1987 \text { ACR criteria, aged } 20 \text { to } 70 \text { years }\end{array}$ & $\begin{array}{l}\text { ACR20 at } \\
\text { week } 24 \text { or } \\
\text { LOCF }\end{array}$ & $\begin{array}{l}\text { TJC, SJC, DAS28, HAQ-DI, } \\
\text { IgG, IgM, IgA, RF, VAS (PAP, } \\
\text { PGA, PhGA), ESR, CRP }\end{array}$ & 4 \\
\hline $\begin{array}{l}\text { Xia et al. } \\
2016[1]\end{array}$ & $\begin{array}{l}\text { RCT, investigator } \\
\text { blinding, single } \\
\text { center }\end{array}$ & China & $\begin{array}{l}\text { January } \\
2013 \text { to } \\
\text { February } \\
2014\end{array}$ & $\begin{array}{l}\text { Active RA patients based on } 1987 \text { ACR } \\
\text { criteria being treated with traditional } \\
\text { DMARDs }\end{array}$ & $\begin{array}{l}\text { ACR20/50/70 } \\
\text { at week } 24\end{array}$ & $\begin{array}{l}\text { Morning stiffness, TJC, SJC, } \\
\text { VAS (PAP, PGA, PhGA), ESR, } \\
\text { CRP, DAS28-ESR, } \\
\text { DAS28-CRP, HAQ }\end{array}$ & 3 \\
\hline $\begin{array}{l}\text { Qi et al. } \\
2019[18]\end{array}$ & $\begin{array}{l}\text { RCT, NR } \\
\text { (blinding), single } \\
\text { center }\end{array}$ & China & $\begin{array}{l}\text { January } \\
2015 \text { to } \\
\text { June } 2018\end{array}$ & $\begin{array}{l}\text { Active RA patients based on } 2012 \text { ACR } \\
\text { criteria, aged } 25 \text { to } 65 \text { years }\end{array}$ & $\begin{array}{l}\text { ACR20 at } \\
\text { week } 24\end{array}$ & $\begin{array}{l}\text { TJC, SJC, DAS28, HAQ, VAS } \\
\text { (PAP PGA PhGA), ESR, CRP }\end{array}$ & 3 \\
\hline $\begin{array}{l}\text { Shi et al. } \\
2015[20]\end{array}$ & $\begin{array}{l}\text { RCT, NR } \\
\text { (blinding), single } \\
\text { center }\end{array}$ & China & $\begin{array}{l}\text { January } \\
2013 \text { to } \\
\text { December } \\
2013\end{array}$ & $\begin{array}{l}\text { Active RA patients based on } 2010 \text { ACR } \\
\text { and EULAR criteria, aged }>18 \text { years, no } \\
\text { history of using traditional DMARDs and } \\
\text { biological agents }\end{array}$ & $\begin{array}{l}\text { ACR20/50/70 } \\
\text { at week } 24\end{array}$ & $\begin{array}{l}\text { TJC, SJC, DAS28, HAQ, VAS } \\
\text { (PAP, PGA, PhGA), ESR, } \\
\text { CRP, SDAI }\end{array}$ & 3 \\
\hline $\begin{array}{l}\text { Mo et al. } \\
2015 \text { [19] }\end{array}$ & $\begin{array}{l}\text { RCT, NR } \\
\text { (blinding), single } \\
\text { center }\end{array}$ & China & $\begin{array}{l}\text { January } \\
2013 \text { to } \\
\text { December } \\
2014\end{array}$ & $\begin{array}{l}\text { Active RA patients based on } 2010 \text { ACR } \\
\text { and EULAR criteria, aged }>18 \text { years }\end{array}$ & $\begin{array}{l}\text { ACR20/50/70 } \\
\text { at week } 12\end{array}$ & $\begin{array}{l}\text { Morning stiffness, TJC, SJC, } \\
\text { DAS28, HAQ, VAS (PAP, } \\
\text { PGA, PhGA), ESR, CRP, RF, } \\
\text { anti-CCP }\end{array}$ & 3 \\
\hline $\begin{array}{l}\text { Zhao et al. } \\
2016[21]\end{array}$ & $\begin{array}{l}\text { RCT, NR } \\
\text { (blinding), single } \\
\text { center }\end{array}$ & China & $\begin{array}{l}\text { June } 2013 \\
\text { to June } \\
2015\end{array}$ & $\begin{array}{l}\text { Active RA patients based on } 1987 \text { ACR } \\
\text { criteria, aged }>18 \text { years }\end{array}$ & $\begin{array}{l}\text { ACR20/50/70 } \\
\text { at week } 24\end{array}$ & $\begin{array}{l}\text { TJC, SJC, DAS28, HAQ, VAS } \\
\text { (PAP, PGA, PhGA) }\end{array}$ & 3 \\
\hline \multicolumn{8}{|c|}{ 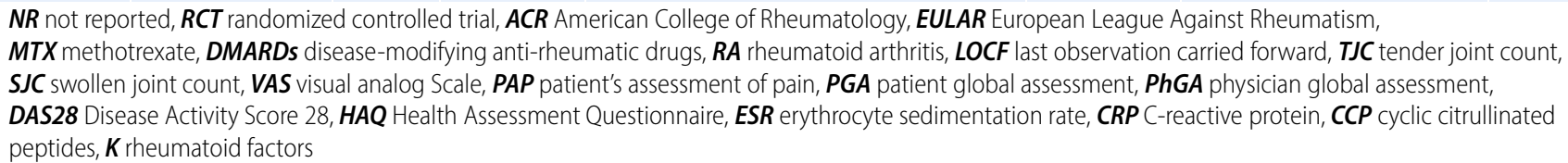 } \\
\hline
\end{tabular}

use of folic acid $5 \mathrm{mg} /$ week [16] or folic acid $10 \mathrm{mg} /$ week [18].

\section{Efficacy of iguratimod combined with methotrexate}

\section{ACR20/50/70}

All seven studies compared the ACR, namely the ACR20, ACR50, and ACR70 between the IGU + MTX group and the MTX/MTX+ placebo group. The heterogeneity $\left(\mathrm{I}^{2}\right)$ values of the ACR20, ACR50, and ACR70 were 0.74 ( $p=0.0008)$, $0(p=0.95)$, and $0(p=0.82)$, respectively; therefore, the random-effects model was used for ACR2 0 and the fixed-effects model was used for ACR50 and ACR70. The ACR was better for the IGU + MTX group, with a pooled relative risk (RR) for ACR20, ACR50, and ACR70 of 1.40 (95\% CI 1.13-1.74), 2.09 (95\% CI 1.67-2.61), and 2.24 (95\% CI 1.53-3.28), respectively (• Fig. 4).

\section{DAS28}

Four studies $[1,16,17,20]$ with a total of 465 participants were included in this meta-analysis (- Fig. 5a). The heterogeneity was minimal $\left(\mathrm{I}^{2}=0 \%\right)$, with no statistical significance $(p=0.99)$. Thus, the fixed-effects model was also used. The results demonstrated a significant decrease in DAS28 (-0.90 [95\% CI $-1.06-0.74])$. All the included studies showed that the combined therapy had a good effect with statistical significance.

\section{ESR and CRP}

Six studies [1, 16-20] that evaluated ESR and CRP levels at the end of treatment were included in the meta-analysis. The heterogeneity was moderate (ESR: $\mathrm{I}^{2}=45 \%, p=0.11$; CRP: $\mathrm{I}^{2}=37 \%$, $p=0.16)$. The random-effects model was used. On pooled analysis (• Fig. 5 b, c), after treatment, the mean decreases in the levels of ESR and CRP were $-12.42 \mathrm{~mm} / \mathrm{h}$
(95\% CI -15.64 to -9.20$)$ and $-7.38 \mathrm{mg} / \mathrm{L}$ (95\% CI -9.78 to -4.99 ), respectively. All the included studies showed that the combined therapy had a statistically significant positive effect.

\section{HAQ, TJC, SJC, and VAS (PAP, PGA, and PhGA)}

Five studies $[1,16-18,20]$ that evaluated HAQ, TJC, SJC, and VAS (PAP, PGA, and PhGA) levels at the end of treatment were included in the metaanalysis. The heterogeneity of HAQ, TJC, SJC, and VAS (PAP) was high (HAQ: $\mathrm{I}^{2}=88 \%, p<0.001$; TJC: $\mathrm{I}^{2}=76 \%$, $p=0.002$; VAS [PAP]: $\mathrm{I}^{2}=83 \%, p<0.001$; and SJC: $\left.\mathrm{I}^{2}=90 \%, p<0.001\right)$. However, the heterogeneity of VAS (PGA) and VAS (PhGA) was minimal (VAS [PGA]: $\mathrm{I}^{2}=0 \%, p=0.70$; VAS $[\mathrm{PhGA}]: \mathrm{I}^{2}=0 \%$, $p=0.47)$, and the fixed-effects model was used. On pooled analysis ( $\bullet$ Fig. 5 d, e), after treatment, the mean decreases in 


\section{Originalien}

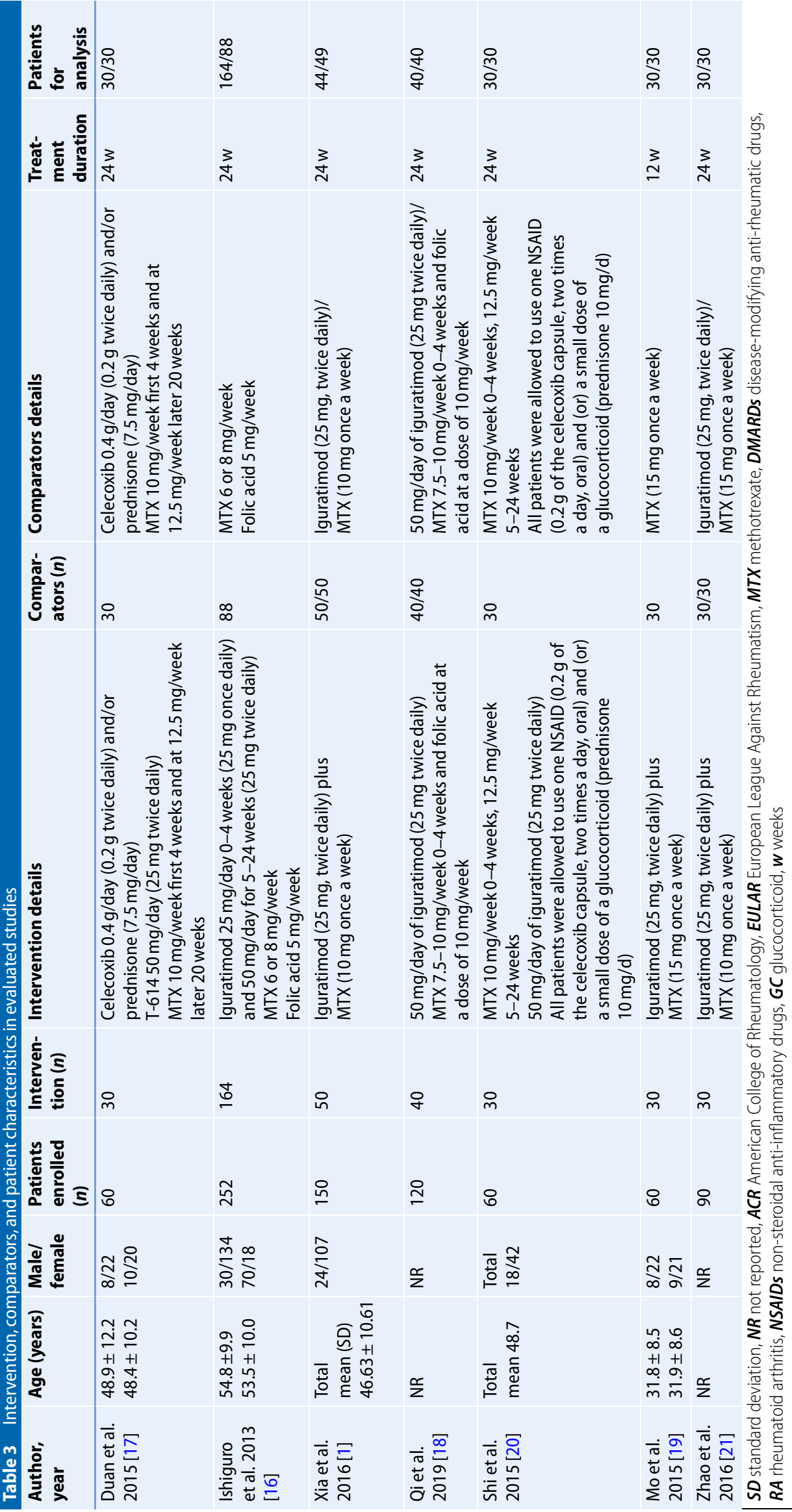




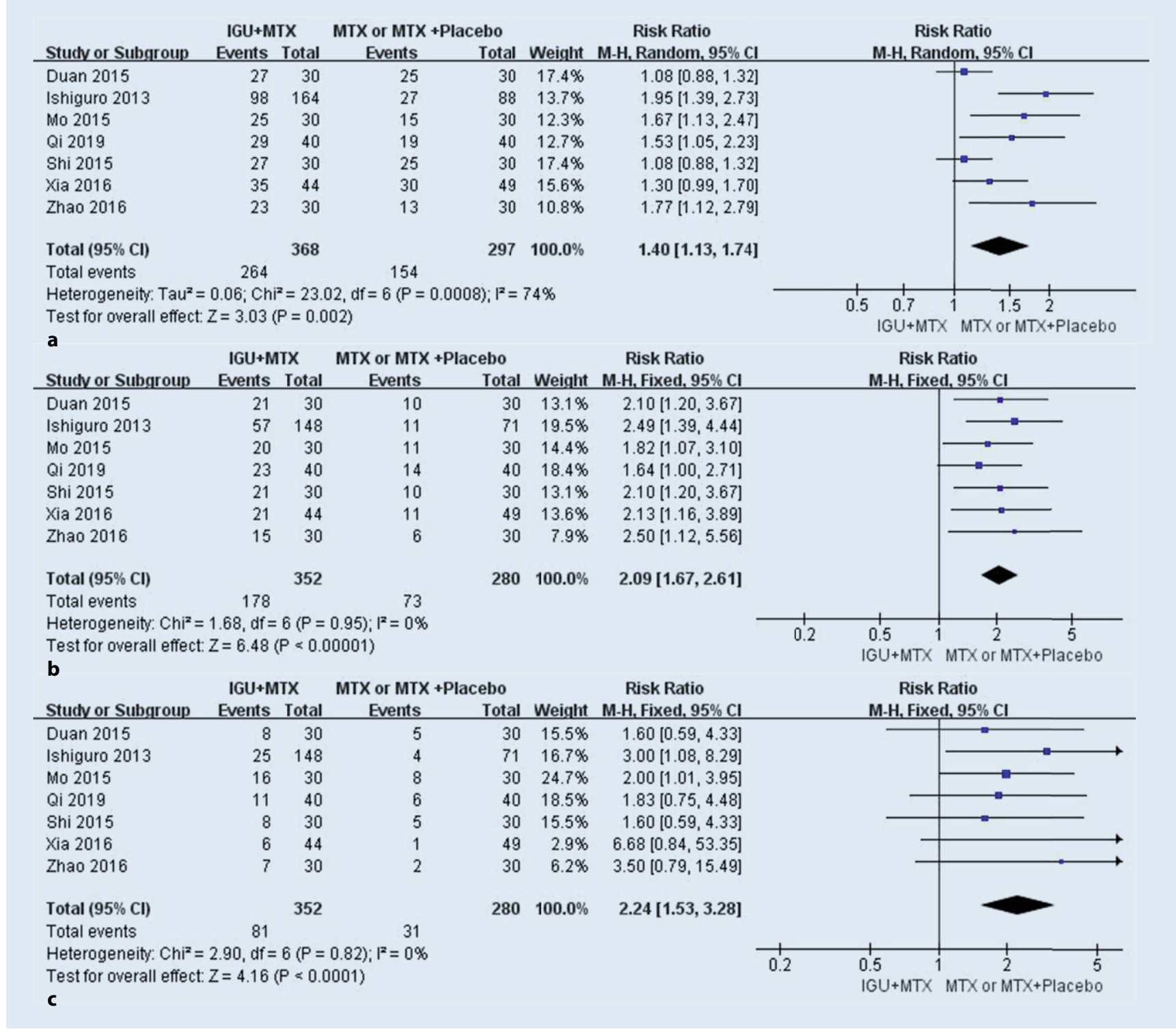

Fig. $4 \Delta$ Comparison of ACR20 (a), ACR50 (b), and ACR70 (c) after treatment between the IGU + MTX group and the MTX group. IGU iguratimod, MTX methotrexate, $M$-H Mantel-Haenszel method, Random random method, $C l$ confidence interval

\begin{tabular}{|c|c|c|c|}
\hline Categories of adverse events & IGU + MTX & $\begin{array}{l}\text { MTX /MTX + } \\
\text { Placebo }\end{array}$ & Risk ratio $(95 \% \mathrm{CI})$ \\
\hline Leukopenia & $35(16 \%)$ & $16(13 \%)$ & $1.18(0.68,2.04)$ \\
\hline Increment in transaminase & $45(20 \%)$ & $31(26 \%)$ & $0.78(0.52,1.17)$ \\
\hline Gastrointestinal disorders & $28(13 \%)$ & $19(16 \%)$ & $0.79(0.46,1.36)$ \\
\hline $\begin{array}{l}\text { Respiratory, thoracic, and mediastinal } \\
\text { disorders }\end{array}$ & $44(20 \%)$ & $22(18 \%)$ & $1.08(0.68,1.71)$ \\
\hline$\beta 2$-microglobulin increased & $24(11 \%)$ & $3(3 \%)$ & $4.31(1.32,14.01)$ \\
\hline Blood iron decreased & $35(16 \%)$ & $16(13 \%)$ & $1.18(0.68,2.04)$ \\
\hline
\end{tabular}

the levels of VAS (PGA) and VAS (PhGA) were $-14.61(95 \%$ CI -17.73 to -11.49$)$ and -12.99 (95\% CI -15.67 to -10.30 ), respectively. Due to variability in the outcomes of HAQ, TJC, SJC, and VAS (PAP), meta-analysis was not feasible. However, in the included studies, there were statistically significant differences between the groups for HAQ, TJC, SJC, and VAS (PAP), which might suggest that IGU could possibly decrease HAQ, TJC, SJC, and VAS (PAP). 


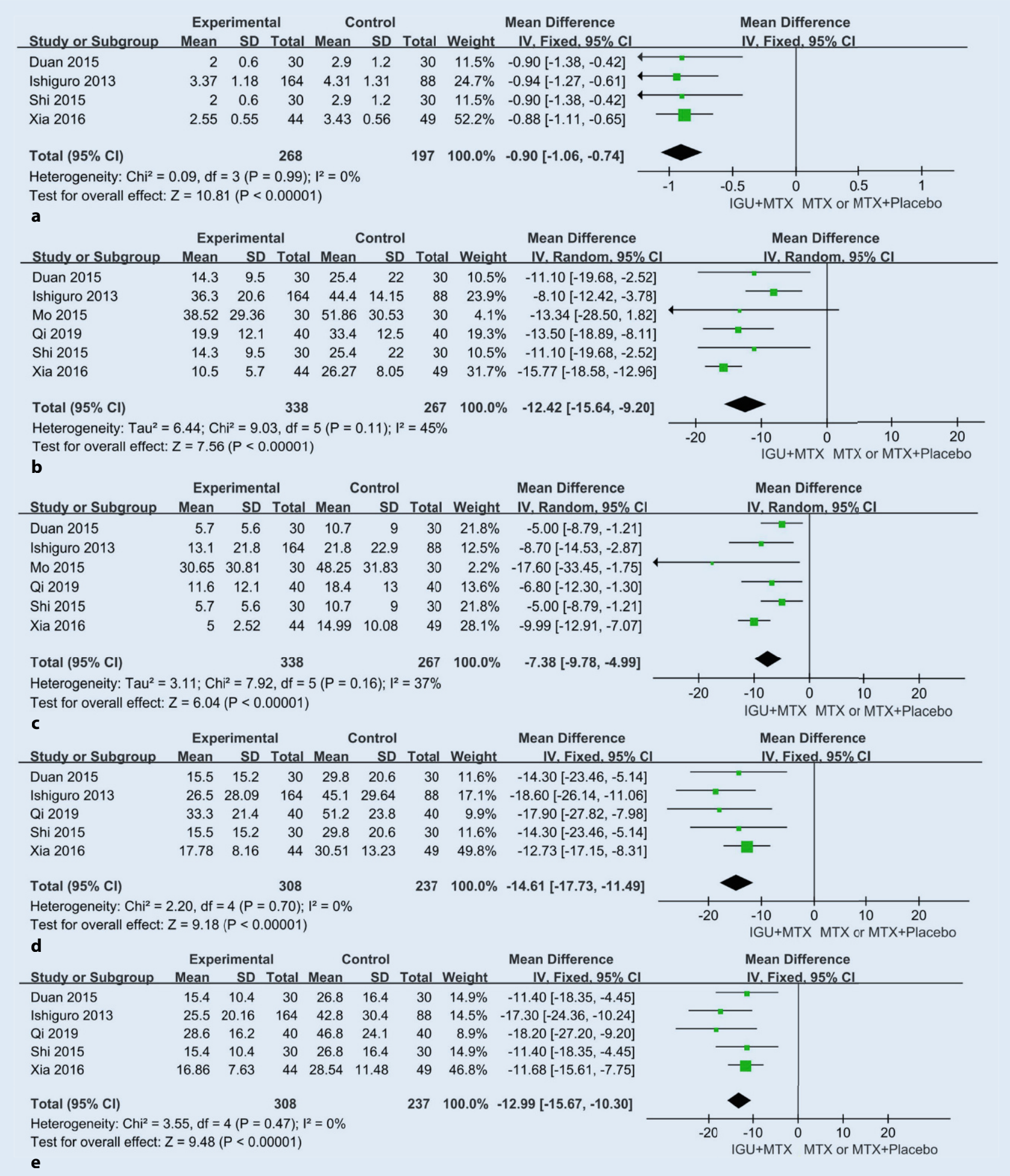

Fig. $5 \Delta$ Comparison of DAS28 (a), ESR (b), CRP (c), VAS (PGA) (d), and VAS (PhGA) (e) after treatment between the IGU+ MTX group and the MTX group. SD standard deviation, IV inverse variance methods, IGUiguratimod, MTX methotrexate, Cl confidence interval 


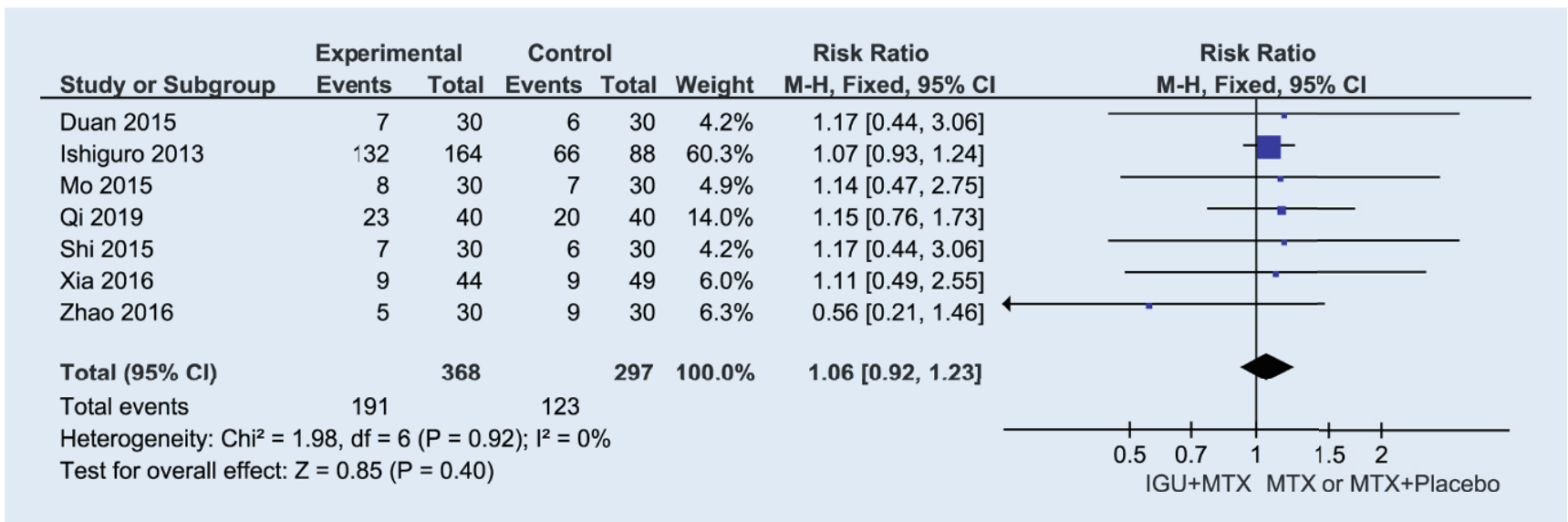

Fig. $6 \Delta$ Analysis of the adverse events in the IGU+MTX group and the MTX group in the treatment of RA. IGUiguratimod, MTX methotrexate, $M$-H Mantel-Haenszel method, Cl confidence interval

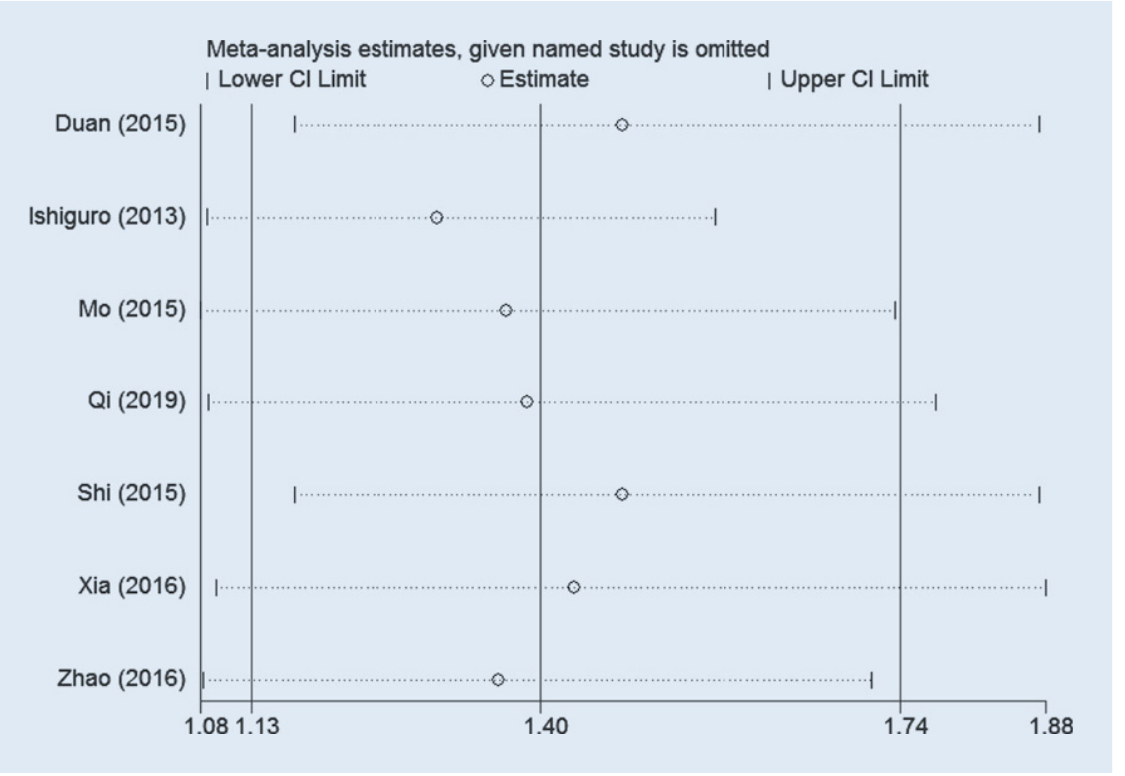

Fig. $7 \Delta$ Sensitivity analysis of ACR20 after treatment between the IGU+MTX group and the MTX group. MTX methotrexate, IGUiguratimod, $\mathrm{Cl}$ confidence interval

\section{The safety of combination therapy}

All seven studies that evaluated adverse events were included in the metaanalysis (- Fig. 6). The heterogeneity was minimal $\left(\mathrm{I}^{2}=0 \%\right)$ without statistical significance $(p=0.92)$. The results demonstrated that there was no statistical significance in adverse events (1.06 [95\% CI 0.92, 1.23]). The pooled RRs were generated by a fixed-effects model (- Table 4). Combination therapy reported more leukopenia ( $16 \%$ vs. $13 \%$ ); respiratory, thoracic, and mediastinal disorders ( $20 \%$ vs. $18 \%$ ); increased $\beta 2$ microglobulin ( $11 \%$ vs. $3 \%)$; and de- creased blood iron (16\% vs. $13 \%)$, but smaller increases in transaminase $(20 \%$ vs. $26 \%)$ and gastrointestinal disorders (13\% vs. $16 \%)$. There were no significant differences between the IGU + MTX and MTX /MTX+placebo groups for all adverse events, except increases in $\beta 2$ microglobulin (RR: 4.31 [95\% CI 1.32, 14.01]). One study [1] reported the adverse event of higher White Blood Cell (WBC) (2\% vs. $3 \% ; p>0.05)$, one study[18] reported the adverse event of headache ( $3 \%$ vs. $3 \% ; p>0.05)$, and two studies $[17,20]$ reported the adverse event of dental ulcer ( $0 \%$ vs. $2 \%$; $p>0.05$ ).

\section{Subgroup and sensitivity analysis}

Due to the high heterogeneity of ACR20, we first checked whether the original data included in the study were correct and whether the method of extracting the data was correct. However, the whole process was normal. We compared the results between the fixedeffects model and the random-effects model for ACR20, and the RR was 1.47 $(95 \%$ CI $1.30,1.67)$ vs. 1.40 (95\% CI 1.13 , 1.74) in the outcome of ACR20. The conclusion of a favorable effect persisted even using different models. Furthermore, sensitivity analysis performed by Stata did not indicate alterations in the results (RR) by sequentially eliminating individual studies, suggesting that no single study significantly contributed to the heterogeneity of ACR20 (- Fig. 7). However, we then performed sensitivity analysis of the outcome of ACR20 by eliminating individual studies from the meta-analysis model in RevMan, the most prominent of which was the study by Ishiguro et al. [16]. After excluding this study, the heterogeneity decreased from 74 to $59 \%$, and the RR decreased from $1.40(95 \% \mathrm{CI} 1.13,1.74)$ to 1.30 (95\% CI 1.08, 1.57); however, the heterogeneity remained high and the RR was still significant, suggesting that this study may be a cause of the source of heterogeneity. Next, we carried out meta-regression and subgroup analysis of language, ACR standard, MTX phase, and complementary drugs. Meta-re- 


\section{Originalien}

\begin{tabular}{|c|c|c|c|c|c|c|c|c|}
\hline \multirow{2}{*}{$\begin{array}{l}\text { Subgroup } \\
\text { analysis }\end{array}$} & & \multirow{2}{*}{$\begin{array}{l}\text { No of } \\
\text { patients }\end{array}$} & \multirow{2}{*}{$\begin{array}{l}\text { No. of } \\
\text { studies }\end{array}$} & \multirow[t]{2}{*}{ Model } & \multirow[t]{2}{*}{$\operatorname{RR}(95 \% \mathrm{Cl})$} & \multirow[t]{2}{*}{$P$-value } & \multicolumn{2}{|c|}{ Heterogeneity } \\
\hline & & & & & & & $I^{2}$ & $P$-value \\
\hline \multirow[t]{2}{*}{ Language } & Chinese & 260 & 4 & Random & $1.435(1.058,1.947)$ & 0.02 & 68.5 & 0.023 \\
\hline & English & 405 & 2 & Fixed & $1.162(0.959,1.407)$ & 0.125 & 27.2 & 0.241 \\
\hline \multirow[t]{2}{*}{ ACR standard } & $1987 A C R$ & 405 & 2 & Fixed & $1.436(1.075,1.917)$ & 0.014 & 27.0 & 0.242 \\
\hline & No $1987 A C R$ & 260 & 4 & Random & $1.250(0.997,1.569)$ & 0.044 & 64.0 & 0.039 \\
\hline \multirow[t]{2}{*}{ MTX phase } & Two phase & 200 & 3 & Random & $1.154(0.952,1.398)$ & 0.145 & 46.9 & 0.152 \\
\hline & Notphased & 465 & 3 & Fixed & $1.304(1.085,1.567)$ & $<0.001$ & 0 & 0.387 \\
\hline \multirow{2}{*}{$\begin{array}{l}\text { Complementary } \\
\text { Drugs }\end{array}$} & NSAIDs or (and) GC or folic acid & 120 & 3 & Random & $1.154(0.952,1.398)$ & 0.145 & 46.9 & 0.152 \\
\hline & Not used & 213 & 3 & Fixed & $1.470(1.205,1.794)$ & $<0.001$ & 0 & 0.387 \\
\hline
\end{tabular}

ACR American College of Rheumatology, EULAR European League Against Rheumatism, $\boldsymbol{M T X}$ methotrexate, DMARDs disease-modifying anti-rheumatic drugs, $\boldsymbol{R A}$ rheumatoid arthritis, $\boldsymbol{N S A I D s}$ non-steroidal anti-inflammatory drugs, $\mathbf{G C}$ glucocorticoid, $\boldsymbol{R} \boldsymbol{R}$ relative risk, $\boldsymbol{C l}$ confidence interval

gression for language, ACR standard, MTX phase, and complementary drugs was not significant $(p=0.429, p=0.923$, $p=0.114, p=0.378$, respectively), indicating that none of these four covariates were the source of heterogeneity. Next, we carried out subgroup analyses of language, ACR standard, MTX phase, and complementary drugs (- Table 5), although the outcome of meta-regression was not significant. Subgroup analysis by language revealed that there was statistical significance in the Chinese group $(\mathrm{RR}=1.435,95 \% \mathrm{Cl}[1.058$, 1.947], $p=0.02$ ), but the English group showed the opposite result $(\mathrm{RR}=1.162$, $95 \% \mathrm{Cl}[0.959,1.407], p=0.125)$. With respect to subgroup analysis by ACR standard, results for both the 1987 ACR standard $(\mathrm{RR}=1.611,95 \% \mathrm{CI}[1.075$, 1.917], $p=0.014)$ and no 1987 ACR standard $(\mathrm{RR}=1.250,95 \% \mathrm{CI}[0.997$, 1.569], $p=0.044$ ) groups suggested obvious statistical significance. According to subgroup analysis by MTX phase, significant RR was found in the no MTX phase group $(\mathrm{RR}=1.304,95 \% \mathrm{CI}$ [1.085, 1.567], $p<0.001$ ), whereas no significant RR was reported in the two MTX phase group $(\mathrm{RR}=1.154,95 \% \mathrm{CI}[0.95$, 1.398], $p=0.145$ ). Subgroup analysis by complementary drugs indicated that the used group $(\mathrm{RR}=1.154,95 \% \mathrm{CI}$ $[0.952,1.398], p=0.145)$ suggested no statistical significance, and the not-used group $(\mathrm{RR}=1.47,95 \% \mathrm{CI}[1.205,1.794]$, $p=0.011)$ marked a favorable effect of combination therapy.

\section{Publication bias}

No evidence of publication bias was detected for the RR of ACR20, ACR50, or ACR70 by either Begg's or Egger's test (RR of ACR20 Begg's $p=0.51$ and Egger's $p=0.62 ;$ RR of ACR50 Begg's $p=0.29$ and Egger's $p=0.34$; RR of ACR70 Begg's $p=0.176$ and Egger's $p=0.065$ ).

\section{Discussion}

To the best of our knowledge, this is the first English systematic review and metaanalysis to compare the efficacy and safety of IGU combined with MTX in RA. According to our results, IGU + MTX had a positive impact on efficacy and safety in patients with RA by both increasing ACR criteria values, namely ACR20, ACR50, and ACR70, and decreasing clinical indexes including DAS28, ESR, CRP, VAS (PGA), and VAS (PhGA). Due to the variability in the outcomes of HAQ, TJC, SJC, and VAS (PAP), meta-analysis was not feasible. However, in the included studies, there were statistically significant differences between the groups for DAS28, ESR, CRP, HAQ, TJC, SJC, and VAS (PAP), which might suggest that IGU + MTX could possibly decrease these indexes.

Our meta-analysis of the main outcomes showed that ACR was better for the IGU + MTX group, with pooled RRs for ACR20, ACR50, and ACR70 of 1.40 (95\% CI 1.13-1.74), 2.09 (95\% CI 1.67-2.61), and 2.24 (95\% CI 1.53-3.28), respectively. Because of the high heterogeneity of ACR20, we performed a series of procedures to search for the source of heterogeneity, including checking the original data and the method used for extracting data repeatedly; performing sensitivity analysis with Stata and RevMan, meta-regression, and subgroup analyses; and changing from the fixed-effects model to the random-effects model. The sensitivity analysis performed by RevMan identified one study [16] in particular. After excluding this study, the heterogeneity decreased from 74 to $59 \%$, and RR decreased from $1.40(95 \%$ CI $1.13,1.74)$ to $1.30(95 \%$ CI, 1.08, 1.57). Hence, we identified two distinguishing factors that might have caused this difference after examining the study carefully. First, the quality of this study was the highest among all included studies, which was mainly reflected in the following aspects: inclusion of the largest number of people $(n=252)$, the highest Jadad score (4 points), rigorous experimental design (4-week observation period and a 24 -week double-blind treatment period), and the phased collection of data ( 0 weeks, 8 weeks, 16 weeks, and 24 weeks). However, the other six studies included a small number of people ( $n=60$ to 100$)$ and had an average Jadad score ( 3 points). The above reasons may lead to greater heterogeneity in the meta-analysis, but this does not mean that the study did not meet the inclusion criteria. Second, when designing this study, the researchers assumed ACR20 response rates of $50 \%$ in the iguratimod group and $25 \%$ in the placebo group, with a sample size of 128 patients and 64 patients (randomization ratio of 2:1). However, ACR20 was higher than 50\% in most of the RCT experimental groups 


\begin{tabular}{|c|c|}
\hline \multicolumn{2}{|c|}{ Abbreviations } \\
\hline$A C R$ & $\begin{array}{l}\text { American College of Rheumatol- } \\
\text { ogy }\end{array}$ \\
\hline$C C P$ & Cyclic citrullinated peptides \\
\hline$C R P$ & C-reactive protein \\
\hline DAS28 & Disease Activity Score 28 \\
\hline DMARDs & $\begin{array}{l}\text { Disease-modifying antirheumatic } \\
\text { drugs }\end{array}$ \\
\hline$E S R$ & Erythrocyte sedimentation rate \\
\hline EULAR & $\begin{array}{l}\text { European League Against } \\
\text { Rheumatism }\end{array}$ \\
\hline GC & Glucocorticoid \\
\hline$H A Q$ & Health Assessment Questionnaire \\
\hline LOCF & Last observation carried forward \\
\hline MTX & Methotrexate \\
\hline$N R$ & Not reported \\
\hline NSAIDs & $\begin{array}{l}\text { Non-steroidal anti-inflammatory } \\
\text { drugs }\end{array}$ \\
\hline$P A P$ & Patient's assessment of pain \\
\hline$P G A$ & Patient global assessment \\
\hline PhGA & Physician global assessment \\
\hline$R C T$ & Randomized controlled trial \\
\hline$R F$ & Rheumatoid factors \\
\hline$S D$ & Standard deviation \\
\hline SJC & Swollen joint count \\
\hline$T J C$ & Tender joint count \\
\hline VAS & Visual analog Scale \\
\hline
\end{tabular}

and $25 \%$ in the placebo group, and most of the RCTs were designed at a randomization ratio of $1: 1$. These factors may have resulted in the ACR20 rate of this study being different from that of other studies and being one of the sources of heterogeneity.

Iguratimod is a novel DMARD for the treatment of RA [1, 5, 22-35], which suppresses tumor necrosis factor-alphainduced production of interleukin (IL)6, IL-8, and monocyte chemoattractant protein 1 via inhibition of nuclear factor kappa B activation in cultured human synovial cells and human acute monocytic leukemia cells, which indirectly inhibits damage to osteoblasts $[16,34,36$, 37]. Moreover, IGU also can reduce immunoglobulin (Ig) production by acting directly on human B lymphocytes with- out affecting proliferation [38]. In addition, by reducing serum levels of tumor necrosis factor-alpha, IL-1-beta, IL17, and IL-6, IGU markedly enhances the therapeutic effect (synergistic effect) of the combined treatment $[33,38,39]$. Because of the different active mode of iguratimod and because the efficacy of the combined treatment of MTX + IGU is better than that of MTX + placebo, the combined treatment is an effective, safe, and economical treatment option for patients who do not respond well to MTX alone or for patients who cannot afford expensive biologics that have no confirmed efficacy.

The event rates of adverse effects were similar in the two groups. The only significant increase in adverse events was an increase in $\beta 2$-microglobulin in one RCT [16]. Moreover, one study [1] reported the adverse event of higher WBCs ( $2 \%$ vs. $3 \% ; p>0.05)$, one study [18] reported the adverse event of headache (3\% vs. $3 \%$; $p>0.05$ ), and two studies $[17,20]$ reported the adverse event of dental ulcer ( $0 \%$ vs. $2 \%$; $p>0.05$ ). Some studies have shown that peculiar hemorrhage (pulmonary alveolar hemorrhage, subcutaneous hemorrhage) was observed with concomitant use of IGU and warfarin $[3,39]$. One study in vivo indicated that the mechanism by which IGU increases the anti-coagulation activity of warfarin is by modulating the production of a blood coagulation factor by the vitamin Kcycle [40]. However, another study in vitro indicated that IGU is a potent direct inhibitor of CYP2C9-mediated warfarin 7-hydroxylation [41]. Further studies should help identify and explore specific mechanisms. No deaths were reported in any of the included studies. Iguratimod combined with methotrexate appeared to be safe and tolerable for RA.

\section{Strengths and limitations}

Our systematic review with meta-analysis has several strengths. We searched the major databases (including trials, gray literature, and unpublished data) with rigorous strategies. Two authors selected the articles independently, allowing a low probability that an important study was missed. The included studies were of high quality. Although the heterogeneity of the ACR20 was high, we performed a series of procedures to detect the source of heterogeneity, including checking the original data and the method of extracting data repeatedly; performing sensitivity analysis by Stata and RevMan, meta-regression, and subgroup analyses; and changing from the fixed-effects model to the randomeffects model. Moreover, there was no significant publication bias. We evaluated all clinical indexes comprehensively, including DAS28, ESR, CRP, VAS (PAP), VAS (PGA), and VAS (PhGA). However, there were some limitations. Firstly, the strength of our research was compromised by the small number of trials[42]. Secondly, no phase III trials were available for analysis. Six trials were singlecenter China-based studies. Only one multicenter Japan-based study remained. Thirdly, the actual molecular targets of IGU are still unknown, which further studies should help to predict. The clinical studies on this drug are mainly short-term, there are no long-term clinical data for more than 3 years. Therefore, multicenter and long-term safety data and comparisons of the safety and effectiveness of IGU with other drugs are necessary. Furthermore, the largest and most rigorous RCT that had the greatest influence on our results was different from the other RCTs regarding the statistical analysis design. Additionally, the tests of publication bias had low power to detect a potential bias. In addition, the people we included in the study were all Asian (mainly Chinese and Japanese) and could be ethnically different. The impact is that our conclusions may not be generalizable to other populations such as Americans or Europeans. In our review, the adverse events of higher WBC, headache, and dental ulcer were reported in only one or two studies. Serious adverse events were reported in one study [16], with 5 patients in the IGU + MTX group (gastroduodenal ulcer, tendon rupture, carbon monoxide poisoning, interstitial lung disease, and retinal hemorrhage), and $\mathrm{Li}$ et al. reported a rare case of severe liver injury. Although no deaths were reported in any 
Hier steht eine Anzeige.

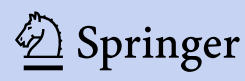


included studies, the safety of combination therapy requires careful monitoring of adverse events throughout iguratimod treatment for diseases.

\section{Conclusion}

Overall, the meta-analysis of RCTs strongly suggests that iguratimod combined with methotrexate is more effective in treating RA than methotrexate alone. It is also worth noting that the incidence of adverse events associated with combination therapy is comparable to methotrexate alone, with the exception of some low-incidence events. Combination therapy is an effective, safe, and economical treatment option for patients who do not respond well to methotrexate alone or for patients who cannot afford expensive biologics that have no confirmed efficacy. Finally, more large multicenter randomized controlled trials, especially non-Asia-Pacific trials, are needed to produce more reliable conclusions.

\section{Corresponding address}

J.-Y. Li
Department of Rheumatology and
Immunology, The Affiliated ZhuZhou Hospital
of XiangYa Medical College, Central South
University
116 South Changjiang Road, 412007 ZhuZhou,
Hunan Province, China
lijingyangcsu@163.com

\section{Compliance with ethical guidelines}

Conflict of interest. L.-J. Chen, Y.-J. Zhou, Z.-H. Wen, F. Tian, and J.-Y. Li declare that they have no competing interests.

For this article no studies with human participants or animals were performed by any of the authors. All studies performed were in accordance with the ethical standards indicated in each case.

Open Access. This article is licensed under a Creative Commons Attribution 4.0 International License, which permits use, sharing, adaptation, distribution and reproduction in any medium or format, as long as you give appropriate credit to the original author(s) and the source, provide a link to the Creative Commons licence, and indicate if changes were made. The images or other third party material in this article are included in the article's Creative Commons licence, unless indicated otherwise in a credit line to the material. If material is not included in the article's Creative Com- mons licence and your intended use is not permitted by statutory regulation or exceeds the permitted use, you will need to obtain permission directly from the copyright holder. To view a copy of this licence, visit http://creativecommons.org/licenses/by/4.0/.

\section{References}

1. Xia Z, Lyu J, Hou N et al (2016) Iguratimod in combination with methotrexate in active rheumatoid arthritis. ZRheumatol 75(8):828-833

2. Singh JA, Saag KG, Bridges SLJ et al (2016) 2015 American college of rheumatology guideline for the treatment of rheumatoidarthritis. Arthritis Care Res 68(1):1-25

3. Mimori T, Harigai M, Atsumi T et al (2016) Safety and effectiveness of 24-week treatment with Iguratimod, a new oral disease-modifying antirheumatic drug, for patients with rheumatoid arthritis: interim analysis of a post-marketing surveillance study of 2679 patients in Japan. Mod Rheumatol 27(5):755-765

4. Du F, Lü L, Teng J et al (2012) T-614 alters the production of matrix metalloproteinases (MMP-1 andMMP-3) and inhibits the migratory expansion of rheumatoid synovial fibroblasts, in vitro. Int Immunopharmacol 13(1):54-60

5. Gan K, Yang L, Xu L et al (2016) Iguratimod (T-614) suppresses RANKL-induced osteoclast differentiation and migration in RAW264.7 cells via NF-KB and MAPKpathways. Int Immunopharmacol 35:294-300

6. Kohno M, Aikawa Y, Tsubouchi Y et al (2001) Inhibitory effect of T-614 on tumor necrosis factoralpha induced cytokineproduction and nuclear factor-kappaB activation in cultured human synovial cells. JRheumatol 28(12):2591-2596

7. Kawakami A, Tsuboi M, Urayama S et al (1999) Inhibitory effect of a new anti-rheumatic drug T-614 on costimulatory molecule expression, cytokine production, and antigen presentation by synovial cells. J Lab Clin Med 133(6):566-574

8. Hara M, Ishiguro N, Katayama K et al (2014) Safety and efficacy of combination therapy of Iguratimod with methotrexate for patients with active rheumatoid arthritis with an inadequate response Tomethotrexate: an open-label extension of a randomized, double-blind,placebo-controlled trial. Mod Rheumatol 24(3):410-418

9. Moher D, Liberati A, Tetzlaff J et al (2009) Preferred reporting items for systematic reviews and metaanalyses: the PRISMA statement. J Clin Epidemiol 62(10):1006-1012

10. Higgins JPT, Altman DG, Gotzsche PC et al (2011) The Cochrane Collaboration's tool for assessing risk of bias in randomised trials. BMJ 343:d5928

11. Jadad AR, Moore RA, Carroll Detal (1996) Assessing the quality of reports of randomized clinical trials: is blindingnecessary? Control Clin Trials 17(1):1-12

12. DerSimonian R, Laird N (1986) meta-analysis in clinical trials. Control Clin Trials 7(3):177-188

13. Higgins JPT (2003) Measuring inconsistency in meta-analyses. BMJ 327(7414):557-560

14. Begg CB, Mazumdar M (1994) Operating characteristics of a rank correlation test for publication bias. Biometrics 50(4):1088-1101

15. Egger M, Davey Smith G (1997) Bias in metaanalysis detected by a simple, graphical test. BMJ 315(7109):629-634

16. Ishiguro N, Yamamoto K, Katayama K et al (2013) Concomitant Iguratimod therapy in patients with active rheumatoid arthritis despite stable doses of methotrexate: a randomized, double- blind,placebo-controlled trial. Mod Rheumatol 23(3):430-439

17. Duan X, Zhang X, Mao S et al (2015) Efficacy and safety evaluation of a combination of Iguratimod and methotrexate therapy for active rheumatoid arthritis patients: a randomized controlled trial. Clin Rheumatol 34(9):1513-1519

18. Qi D, Liu Y, Huang D et al (2019) Efficacy and safety evaluation of a combination of Iguratimod and Methotrexate therapy for active rheumatoid arthritis patients. Chin J Drug Eval 36(03):217-220

19. Mo H, Ma S (2015) Clinical study of a combination of Iguratimod and methotrexate therapy for active rheumatoid arthritis patients. Intern Med China 10(02):156-159

20. Shi X, Zhang X, Duan X et al (2015) Efficacy and safety evaluation of a combination of iguratimod and methotrexate therapy for active rheumatoid arthritis patients. J Nanchang Univ Sci 55(01):33-36

21. Zhao W, Yao D, Huo H et al (2016) Clinical study of Iguratimodfor active rheumatoid arthritis patients. Chin J Postgraduates Med 10(02):156-159

22. Song J, Liu H, Zhu Q et al (2018) T-614 promotes osteoblastic cell differentiation by increasing Dlx5 expression and regulating the activation of $\mathrm{p} 38$ and NF-KB. Biomed Res Int 2018:1-8

23. Sun Y, Ye D, Zhang P et al (2016) Anti-rheumatic drug Iguratimod (T-614) alleviates cancer-induced bone destruction via down-regulating interleukin- 6 production in a nuclear factor-кBdependent manner. J Huazhong Univ Sci Technol Med Sci 36(5):691-699

24. Liu D, Liu CF, Wang N et al (2014) The research of effects of lguratimod(T-614) on the apoptosis of peripheral blood mononuclear cell and $\mathrm{TH} 1$ in rheumatoid arthritis. Value Health 17(7):A772

25. Li G, Yamasaki R, Fang M et al (2018) Novel disease-modifying anti-rheumatic drug Iguratimod suppresses chronic experimental autoimmune encephalomyelitis by down-regulating activation of Macrophages/Microglia through an NF-KB pathway. Sci Rep 8(1):1933

26. Wu Y, Sun Y, Ye Y et al (2017) Iguratimod prevents ovariectomy-induced Bone loss and suppresses osteoclastogenesis via inhibition of peroxisome proliferator-activated receptor- $Г$. Mol Med Rep 16(6):8200-8208

27. Jiang X, Huang X, Yang Z et al (2018) Iguratimod ameliorates inflammatory responses by modulating the th17/Treg paradigm in dextran sulphate sodium-induced murine colitis. Mol Immunol 93:9-19

28. Du F, Lü L, Fu Q et al (2008) T-614, a novel immunomodulator, attenuates joint inflammation and articular damage in collagen-induced arthritis. Arthritis Res Ther 10(6):R136

29. Tanaka K, Kawasaki H, Kurata Ket al (1995) T-614, a Novel Antirheumatic Drug, Inhibits Both the Activity and Induction Ofcyclooxygenase-2 (COX2) in Cultured Fibroblasts. Nippon Yakurigaku Zasshi67(4):305-314

30. Mucke HA (2012) Iguratimod: a new diseasemodifying antirheumatic drug. Drugs Today (Barc) 48:577-586

31. Aikawa Y, Tanuma N, Shin Tet al (1998) A new antirheumatic drug, T-614, effectively suppresses the development ofautoimmune encephalomyelitis. JNeuroimmunol 89(1-2):35-42

32. Kuriyama K, Higuchi C, Tanaka K et al (2002) A novel anti-rheumatic drug, T-614, stimulates osteoblastic differentiation invitro and bone morphogenetic protein-2-induced bone formation in vivo. Biochem Bioph Res Co 299(5):903-909 
33. Luo Q, Sun Y, Liu W et al (2013) A novel diseasemodifying antirheumatic drug, iguratimod, ameliorates murine arthritis by blocking IL17 signaling, distinct from methotrexate and leflunomide. JImmunol 191(10):4969-4978

34. Hara M, Abe T, Sugawara S et al (2007) Longterm safety study of iguratimod in patients with rheumatoid arthritis. Mod Rheumatol 17(1):10-16

35. Xia Y, Zhao S, Gong M et al (2018) A rapid and sensitive LC-MS/MS method for analysis of Iguratimod in human plasma: application to a pharmacokinetic study in Chinese healthy volunteers. Biomed Chromatogr 32(9):e4277

36. Tanaka K, Shimotori T, Makino S et al (1992) Pharmacological studies on3-formylamino-7methylsulfonylamino-6-phenoxy-4H-1-benzopyran-4-one (T-614), anovel anti-inflammatory agent. 3rd communication: the involvement of Bradykinin Inits analgesic actions. J Pharmacobiodyn 15(11):641-647

37. Aikawa Y, Yamamoto M, Yamamoto T et al (2002) An anti-rheumatic agent T-614 inhibits NF-kappaB activation in LPS- andTNF-alpha-stimulated THP-1 cells without interfering with Ikappa Balpha degradation. Inflamm Res 51(4):188-194

38. Yoshikawa A, Yoshida S, Kimura Y et al (2017) Add-on Iguratimod as a therapeutic strategy to achieve remission in patients with rheumatoid arthritis inadequately responding to biological DMARDs: a retrospective study. Mod Rheumatol 28(2):227-234

39. Ishikawa K, Ishikawa J (2018) Iguratimod, a synthetic disease modifying anti-rheumatic drug inhibiting the activation of NF-KB and production of RANKL: its efficacy, radiographic changes, safety and predictors over two years' treatment for Japanese rheumatoid arthritis patients. Mod Rheumatol 29(3):418-429

40. Yamamoto T, Hasegawa K, Onoda M et al (2016) Pharmacokinetic and pharmacodynamic analyses of drug-drug interactions between iguratimod and warfarin. Yakugakku Zasshi 136:905-911

41. Satoshi Y, Ken T, Ayaka S et al (2015) In vitro inhibition of CYP2C9-mediated warfarin 7-hydroxylation by Iguratimod: possible mechanism of iguratimod-warfarin interaction. Biol Pharm Bull 38:441-447

42. Chang P, Chiang C, Ho W et al (2015) Combination therapy of varenicline with nicotine replacement therapy is Betterthan varenicline alone: a systematic review and meta-analysis of randomized controlled trials. BMC Public Health 15:689

\section{Christoph Klein, Jan-Maximilian Zeller Strafrechtliche Risiken des Arztes}

Ecomed Medizin Verlag 2021, 168 S., (ISBN: 978-3-609-16538-7), 39,99 EUR

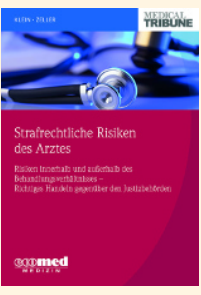

Der medizinische Alltag wird zunehmend durch gesetzliche Vorgaben reguliert. Ärzte sollten nicht nur ihr jeweiliges medizinisches

Fachgebiet beherrschen, sondern auch sich für die generellen, juristischen Rahmenbedingungen interessieren.

Das Buch Strafrechtliche Risiken des Arztes beleuchtet in erfrischend verständlicher Sprache prägnant die juristischen Aspekte im klinischen Alltag.

Das Buch ist in drei Sektionen unterteilt. Der erste Abschnitt bezieht sich konkret auf Handlungsabläufe in der Patientenversorgung. Es werden die im Alltag relevanten medizinischen Teilbereiche abgehandelt. Beginnend mit der Thematik "Aufklärung und Einwilligung", über urologische Tätigkeitsschwerpunkte, allgemeine, ärztliche Hilfspflichten, Aspekte bezüglich Zeugnisausstellungen, Schweigepflicht oder auch Sterbehilfe werden die jeweiligen Kapitel für den Kliniker mit Verweis auf die entsprechenden Gesetze fokussiert vorgestellt.

Der zweite Abschnitt behandelt das Themenfeld außerhalb der Behandlung im Praxisalltag. Unter anderem werden die Tatbestände Korruption, strafbare Werbung und Abrechnungsbetrug beleuchtet.

Der letzte Abschnitt behandelt das Auftreten gegenüber Justizbehörden. Dieser Abschnitt ist ebenfalls ein wesentlicher Bestandteil, da nicht nur Verhaltensregeln in der Rolle des Beschuldigten, sondern auch bei Durchsuchungen dargelegt werden. Auch die standesrechtlichen Aspekte bzw. Konsequenzen werden erläutert.
Die Kapitel sind verständlich aufgebaut und wichtige Informationen werden farblich prägnant hervorgehoben. Fallbeispiele unterstützen die Vermittlung der Inhalte didaktisch sinnvoll.

Dieses Buch ist für klinisch tätige Ärzte absolut lesenswert und nützlich, um die Aufmerksamkeit für juristische bzw. strafrechtliche Gegebenheiten zu schärfen.

C. Spies, Bad Rappenau 